\title{
Diet of Cuvier's beaked whales Ziphius cavirostris from the North Pacific and a comparison with their diet world-wide
}

\author{
Kristi L. West ${ }^{1, *}$, William A. Walker ${ }^{2}$, Robin W. Baird ${ }^{3}$, James G. Mead ${ }^{4}$, \\ Paul W. Collins ${ }^{5}$ \\ ${ }^{1}$ Department of Natural Sciences, Hawai'i Pacific University, Kaneohe, HI 96744, USA \\ ${ }^{2}$ Marine Mammal Laboratory, Alaska Fisheries Science Center, NOAA, 7600 Sand Point Way N.E., Seattle, WA 98115, USA \\ ${ }^{3}$ Cascadia Research Collective, $218{ }^{1 / 2}$ W. $4^{\text {th }}$ Avenue, Olympia, WA 98501, USA \\ ${ }^{4}$ Division of Mammals, Smithsonian Institution, Washington, DC 20013-7012, USA \\ ${ }^{5}$ Department of Vertebrate Zoology, Santa Barbara Museum of Natural History, 2559 Puesta Del Sol, Santa Barbara, CA 93105, USA
}

\begin{abstract}
Cuvier's beaked whales Ziphius cavirostris are distributed world-wide and are recognized as vulnerable to anthropogenic noise. They are the most common cetacean to strand in temporal and spatial proximity to navy sonars. Cuvier's beaked whales are known for their extreme diving capabilities, but diet information, fundamental to understanding foraging at depth, is limited from most regions. We report on 11441 prey items from stomach contents of 16 stranded or bycaught specimens collected between 1976 and 2016 across the North Pacific. Overall diet was composed of cephalopods, fish, and crustaceans, but was dominated by cephalopods. Thirty-seven cephalopod species representing 16 families contributed $98.0 \%$ by number and $87.7 \%$ by mass. The families Gonatidae ( $26.4 \%$ by number; $40.4 \%$ by mass), Octopoteuthidae ( $27.0 \%$ by number; $20.2 \%$ by mass) and Cranchiidae ( $27.2 \%$ by number; $10.7 \%$ by mass) were dominant. The majority of prey items (7997) were from an adult male stranded in California (USA) which contained 20 species from 10 families of cephalopods and fishes. Regional variation was suggested by a higher incidence of crustaceans from whales in the western Pacific, and fishes in the eastern Pacific. Our results combined with data in the literature reveal that world-wide, the most important cephalopod families in the diet are Cranchiidae, Gonatidae, Histioteuthidae, Octopoteuthidae, Ommastrephidae, Onychoteuthidae, Pholidoteuthidae, and Mastigoteuthidae, with Cranchiidae comprising important prey in all locations. While Gonatidae, Octopoteuthidae, and Cranchiidae are the dominant prey in the North Pacific, Histioteuthidae and Cranchiidae are most important in the North Atlantic. Knowledge of diet composition can be used to understand how whales utilize their habitat, in the calculation of nutritional requirements, and may also help to define the locations of important foraging grounds.
\end{abstract}

KEY WORDS: Stomach contents $\cdot$ Food habits $\cdot$ Foraging $\cdot$ Predator $\cdot$ Prey $\cdot$ Cephalopod

\section{INTRODUCTION}

Despite intensive studies for more than a decade, the beaked whales, family Ziphiidae, remain the world's most poorly known group of whales. Several species of beaked whales are recognized as susceptible to impacts from anthropogenic sounds (see Cox et

${ }^{*}$ Corresponding author: kwest@hpu.edu al. 2006), and studies have demonstrated that beaked whales may cease foraging and move out of areas when exposed to high-intensity navy sonars (Tyack et al. 2011, DeRuiter et al. 2013). Recent evidence from survey data and strandings suggest that Cuvier's beaked whale Ziphius cavirostris and Mesoplodon spp. abundances are in decline in the north-

(C) The authors 2017. Open Access under Creative Commons by Attribution Licence. Use, distribution and reproduction are unrestricted. Authors and original publication must be credited. 
ern part of the California Current (Moore \& Barlow 2013). Although the cause of the decline is unknown, anthropogenic sound and ecosystem change are suggested as possible factors. Efforts to model the energetics of beaked whales indicate that in the absence of energetically dense prey, inter-calf interval will be extended, resulting in lowered reproductive rates (New et al. 2013). Despite such recognized beaked whale conservation concerns, there is a general lack of fundamental diet information to better understand beaked whale foraging behavior and how these whales utilize their habitat.

Cuvier's beaked whales are distributed throughout the world's oceans with the exception of the polar seas. They are the most commonly reported beaked whale among the 22 currently recognized species (Heyning \& Mead 2009). However, dietary information from Cuvier's beaked whales inhabiting any of the world's ocean basins is relatively limited as assessing diet for many species of cetaceans is difficult, given that most foraging occurs far below the surface. This is especially true for Cuvier's beaked whales, which forage between about 600 and almost $3000 \mathrm{~m}$ in depth (Baird et al. 2006, 2008, Tyack et al. 2006, Schorr et al. 2014). Prey identification from stomach content analysis has only been conducted for fewer than 50 individuals world-wide, with a bias of approximately $65 \%$ towards males. The majority of Cuvier's beaked whale stomachs examined have come from stranded specimens in the North Atlantic $(\mathrm{n}=20)$ or Mediterranean $(\mathrm{n}=$ 12), where findings have been reported in a number of separate studies (Podesta \& Meotti 1991, Carlini et al. 1992, Blanco \& Raga 2000, Lefkaditou \& Poulopoulos 1998, Santos et al. 2001, 2007, Spitz et al. 2011). When considering the total number of prey items identified among Cuvier's beaked whales examined world-wide, the data available are heavily weighted towards the North Atlantic. Over 8000 prey items were identified from an individual specimen stranded near Scotland (Santos et al. 2001), and prey was identified from 10 specimens stranded over a $10 \mathrm{yr}$ period in the Bay of Biscay (Spitz et al. 2011) and from 7 specimens stranded in the Canary Islands (Santos et al. 2007). In the Southern Hemisphere, Cuvier's beaked whale stomach content remains have been identified from 5 individuals from South Africa (Ross 1984, Sekiguchi 1994) and 1 whale from New Zealand (Fordyce et al. 1979). In the Caribbean and the Gulf of Mexico, individual Cuvier's beaked whale strandings provide limited data on diet from these regions (Debrot \& Barros 1994, Fertl et al. 1997).
Little is known of the diet of Cuvier's beaked whales in the North Pacific. Cephalopod species have only been previously identified from 2 stomach samples from Alaska, 1 from California, 1 from Taiwan, and 1 from Japan (Foster \& Hare 1990, Wang et al. 1995, Fiscus 1997, Ohizumi \& Kishiro 2003, Adams et al. 2015). Cuvier's beaked whale diet has not previously been described from any location in the central North Pacific, and large geographical gaps remain between the dietary information available from Alaska, California, and Japan. Here we report on stomach contents from stranded or bycaught Cuvier's beaked whales across the North Pacific Ocean collected over a $40 \mathrm{yr}$ span. Our findings represent an extensive geographic range, with samples collected from Guam and Saipan in the Western Pacific to Panama in the East. We also sampled individuals from the central Pacific, including specimens stranded in Hawai'i and the Aleutian Islands (Fig. 1). We identify prey from available stomach contents to describe the diet composition and prey size from the North Pacific, and compare diet composition to what is known about the diet of this species elsewhere.

\section{MATERIALS AND METHODS}

Stranded or bycaught Cuvier's beaked whale stomach contents were initially frozen and later thawed, and curated at the Marine Mammal Laboratory (MML) at the Alaska Fisheries Science Center, Hawai'i Pacific University, the Natural History Museum of Los Angeles County (LACM), the Santa Barbara Museum of Natural History (SBMNH), or at the Smithsonian Institution (USNM). Following thawing, invertebrate remains were then preserved in $70 \%$ ethanol for longer-term storage or immediately processed for sorting. Stomach contents were rinsed through a progression of sieves with decreasing mesh sizes of 1.4, 0.94, and $0.50 \mathrm{~mm}$. After sorting, cephalopod beaks and fish bones were preserved in $70 \%$ ethanol. Fish otoliths were stored dry in gelatin capsules. All remains were identified to the lowest possible taxon using the private reference collection of W.A. Walker and the fish bone, otolith, and cephalopod beak reference collections housed at the MML. A voucher series of select beaks and otoliths representing each prey taxon were removed from the individual stomach samples and incorporated into the MML cephalopod beak reference collection.

The total number of each species of cephalopod was estimated as the number of lower beaks present. The total number of each fish species was estimated 


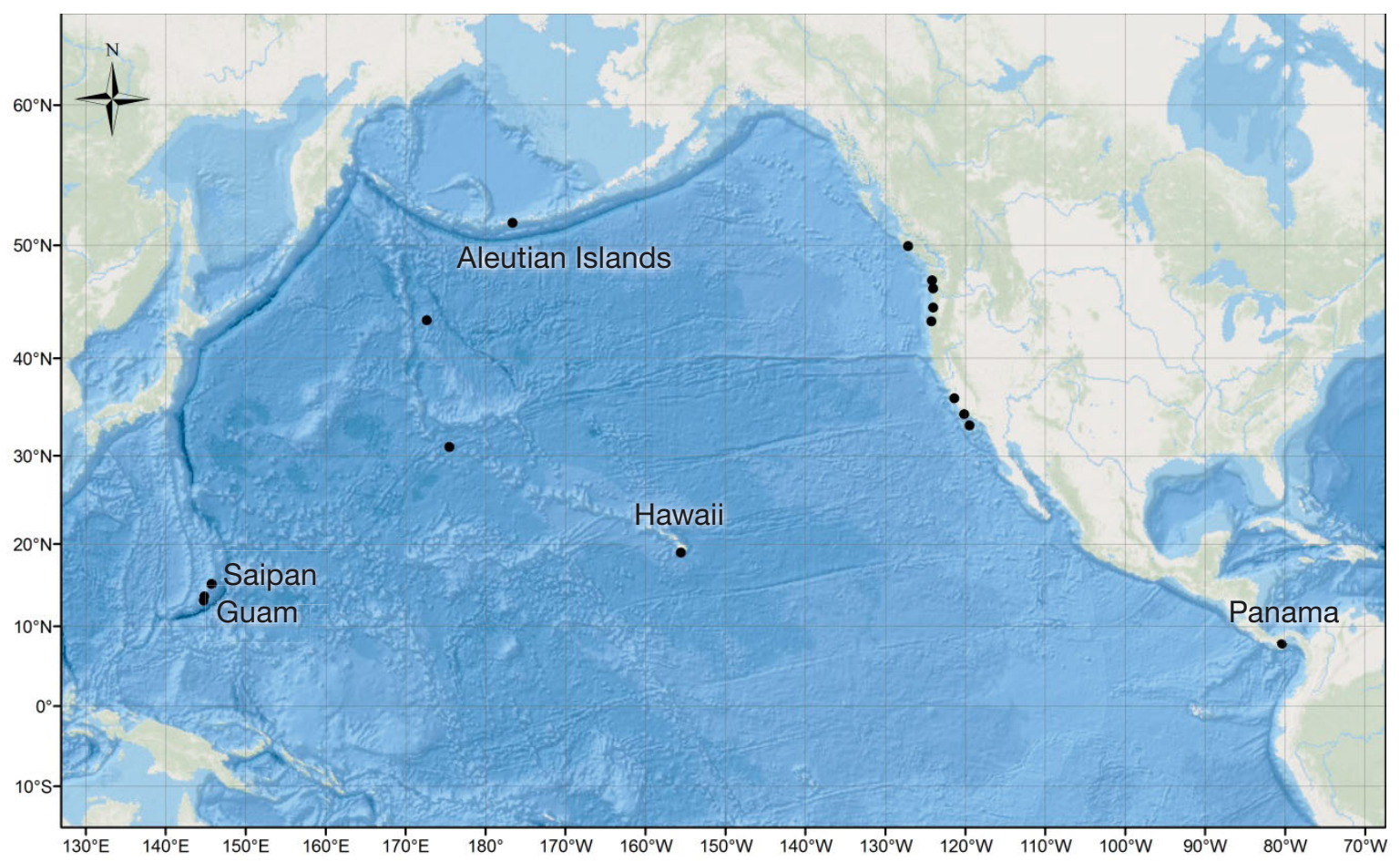

Fig. 1. Locations of stranded and bycaught North Pacific Cuvier's beaked whales Ziphius cavirostris specimens where stomach contents were collected between 1976 and 2016

based on the greater number of left or right otoliths, with 1 exception. In stomach sample SBMNH 8991, the number of basioccipital cranial bones of the giant grenadier Albatrossia pectoralis exceeded the number of left or right otoliths present, so the total number of these bones was used to estimate the minimum number of A. pectoralis present. Crustacean abundance was estimated using the number of individual carapace remains in each stomach or the greater number of anterior or posterior carapace portions in the case of partial remains.

Dorsal mantle length and total weights were estimated by measuring lower beak rostral length for the decapod cephalopods and lower beak hood length for the cephalopods Vampyromorpha and Octopoda and then applying the appropriate regression equations. Cephalopod beaks were measured to the nearest $0.1 \mathrm{~mm}$ with either an optical micrometer or, in the case of large beaks, Vernier calipers. In most cases, regression equations from Wolff $(1982,1984)$, Clarke (1986), Sinclair et al. (2015), and unpublished regressions developed at the MML were used to estimate prey size and mass for the cephalopod species present. If no regression equations were available, prey sizes were estimated using data from taxonomically related individuals of near equivalent beak size.
Fish otoliths and diagnostic bones were measured to the nearest $0.1 \mathrm{~mm}$ using an optical micrometer. Fish prey standard lengths and weights were estimated using regression equations from the literature (Smale et al. 1995, Spear et al. 2007, Sinclair et al. 2015) or, if unavailable, from regressions developed for similar, closely related species at the MML. Carapace lengths were also measured to the nearest $0.1 \mathrm{~mm}$ using Vernier calipers. Weights for all 3 species of shrimp encountered in this study were estimated using regressions developed by Childress \& Price (1983) for another deepwater shrimp, Gnathophausia ingens, since species-specific weight regressions were unavailable.

\section{RESULTS}

Stomach contents were collected from 16 individuals from the North Pacific Ocean (Fig. 1); of these, 14 were individuals that had stranded between 1976 and 2016, and 2 individuals were collected from the Japanese high seas squid drift-net fishery in 1990 and 1991 (Table 1). Eleven of the whales were male, 3 were female, and sex was unknown for 2 specimens. Like other areas where stomach contents of 
Table 1. Cuvier's beaked whales Ziphius cavirostris stranded or bycaught in the North Pacific between 1976 and 2016 , for which stomach contents were examined. Specimens were curated at the Marine Mammal Laboratory, Alaska Fisheries Science Center, the Natural History Museum of Los Angeles County (LACM), the Santa Barbara Museum of Natural History (SBMNH), the Smithsonian Institution (USNM), or Hawai'i Pacific University. Some of the specimen IDs reflect field IDs that were assigned at the time of collection. F: female, M: male, Unk: unknown; est.: estimated, WA: Washington State, CA: California, OR: Oregon, AK: Alaska. Dates are given as mm/dd/yyyy

\begin{tabular}{|c|c|c|c|c|}
\hline Specimen ID & $\begin{array}{l}\text { Date of stranding/ } \\
\text { collection }\end{array}$ & Sex & $\begin{array}{c}\text { Body } \\
\text { length }(\mathrm{cm})\end{array}$ & Location of stranding/collection \\
\hline EHS-022 & 09/27/1990 & M & 574 & $43^{\circ} 32^{\prime} \mathrm{N}, 172^{\circ} 38^{\prime} \mathrm{E}^{\mathrm{a}}$ \\
\hline JAS-038 & 03/25/1991 & M & 560 & $30^{\circ} 59^{\prime} \mathrm{N}, 175^{\circ} 28^{\prime} \mathrm{E}^{\mathrm{a}}$ \\
\hline CRC-442 & $11 / 19 / 1998$ & M & 572 & Oyhut Beach, Ocean Shores, WA \\
\hline SWDP 93-18 & 05/17/1993 & $\mathrm{F}$ & 590 & North Gregoire Point, Vancouver Island, British Columbia, Canada \\
\hline NMML 1681 & $11 / 14 / 1994$ & Unk. & 305 (est.) & Long Beach, WA \\
\hline LACM 88971 & 09/21/1993 & $\mathrm{F}$ & 537 & San Nicholas Island, Ventura County, CA \\
\hline USNM 504347 & 04/17/1976 & Unk. & 467 & Agate Beach, OR \\
\hline USNM 51922 & $10 / 28 / 1976$ & $\mathrm{~F}$ & 600 (est.) & Los Santos, Panama \\
\hline STRO 03674 & 07/31/1981 & M & 584 & Clam Lagoon, Adak Island, AK \\
\hline MME 3044 & $06 / 13 / 1987$ & M & 540 & Horsefall Beach, Coos Bay, OR \\
\hline KW2011016 & 08/23/2011 & M & 439 & Saipan Lagoon, Saipan \\
\hline KW2015003 & $03 / 23 / 2015$ & M & 480 & Merizo, Guam \\
\hline KW2015010 & $07 / 26 / 2015$ & $\mathrm{M}$ & 516 & Agat, Guam \\
\hline KW2016005 & $05 / 15 / 2016$ & $\mathrm{M}$ & 533 & Ka'alualu Bay, South Point, Hawai'i \\
\hline SBMNH 8991 & 05/09/2006 & M & 591 & San Simeon State Park, San Luis Obispo, CA \\
\hline SBMNH 9146 & 08/07/2010 & M & 594 & Santa Cruz Island, Santa Barbara, CA \\
\hline
\end{tabular}

this species have been collected, our sample is biased towards males, and thus our results are relevant primarily to the diet of male Cuvier's beaked whales.

Together, the 16 whale stomachs contained a total of 11441 food items ranging from 1 to 7997 items per stomach $($ median $=61)$. All stomachs examined contained cephalopod remains. Fishes were present in 3 of the 16 stomachs $(18.9 \%)$, and crustacean remains were present in $5(31.3 \%)$. The number of prey items in each stomach varied, with almost $70 \%$ of the prey remains (7997) coming from a single adult male stranded near San Simeon in San Luis Obispo County, California (SBMNH 8991). Although our results are weighted numerically towards the California coast, less than half of the prey species represented in this study were among the remains of SBMNH 8991.

Overall, the diet composition of cephalopods, fish, and crustaceans varied when considering the contribution by prey number as compared to prey mass. Cephalopods represented $98.0 \%$ of the diet by number and $87.7 \%$ by mass. Fishes represented only $1.1 \%$ of the diet of the whales by number but $12.1 \%$ by mass. Despite being present in $31.3 \%$ of the stomachs, crustaceans only represented $1.5 \%$ of the diet by number and $0.3 \%$ by mass.

Fish remains found among the whale stomachs represented 5 different species, with each species representing a different family. Four of the 5 fish species identified were represented by only an individual specimen in one of the stomachs. The giant grenadier, from the family Macrouridae, was present in high abundance (126 specimens) in SBMNH 8991, which accounted for virtually all of the fish prey contribution by mass $(12.1 \%)$ and by number $(1.1 \%)$. Prey size of the giant grenadier based on pre-anal fin length ranged between 199 and 335 mm (Fig. 2).

Crustacean remains were present in $5(31.3 \%)$ of the stomachs but only represented a small contribution by both prey number (1.5\%) and mass (0.3\%) (Fig. 3). Two families of crustacean were present (Oplophoridae and Pasiphaeidae), representing at least 3 different species with a greater contribution of Pasiphaeidae by number $(0.9 \%)$ and mass $(0.2 \%)$ (Table 2$)$.

Cephalopods were found in all of the stomachs and represented the highest contribution to the diet both by number $(98.0 \%)$ and mass $(87.7 \%)$. A total of 11136 lower beaks were identified that represented 16 families and at least 37 different species. The families Cranchiidae, Gonatidae, and Octopoteuthidae were present in over half of the stomachs and were substantial in their contributions to the whales' diet both by number and mass (Fig. 3). Nine of the species of the family Gonatidae had the greatest contribution by mass (40.4\%) and also contributed significantly by 


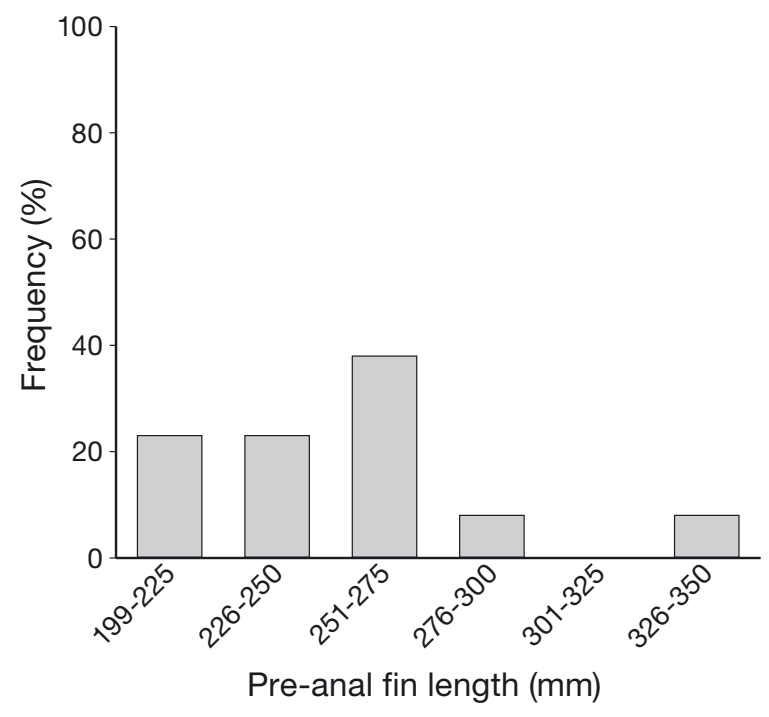

Fig. 2. Pre-anal fin length of giant grenadier Albatrossia pectoralis specimens identified from North Pacific Cuvier's beaked whale Ziphius cavirostris stomach contents

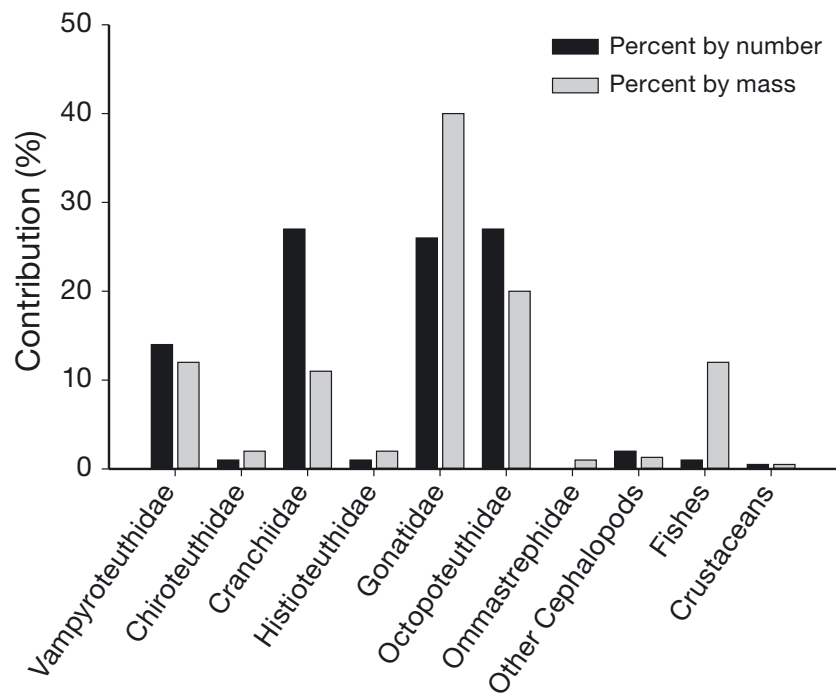

Fig. 3. Overall contribution by number and by mass of cephalopod prey families, fishes, and crustaceans to Cuvier's beaked whale Ziphius cavirostris diet in the North Pacific

Table 2. Prey species identified from stomach contents of 16 Cuvier's beaked whales Ziphius cavirostris examined in the North Pacific. Prey length measurements are pre-anal fin length for Albatrossia pectoralis, standard length for other fishes, dorsal mantle length for cephalopods, or carapace length for crustaceans

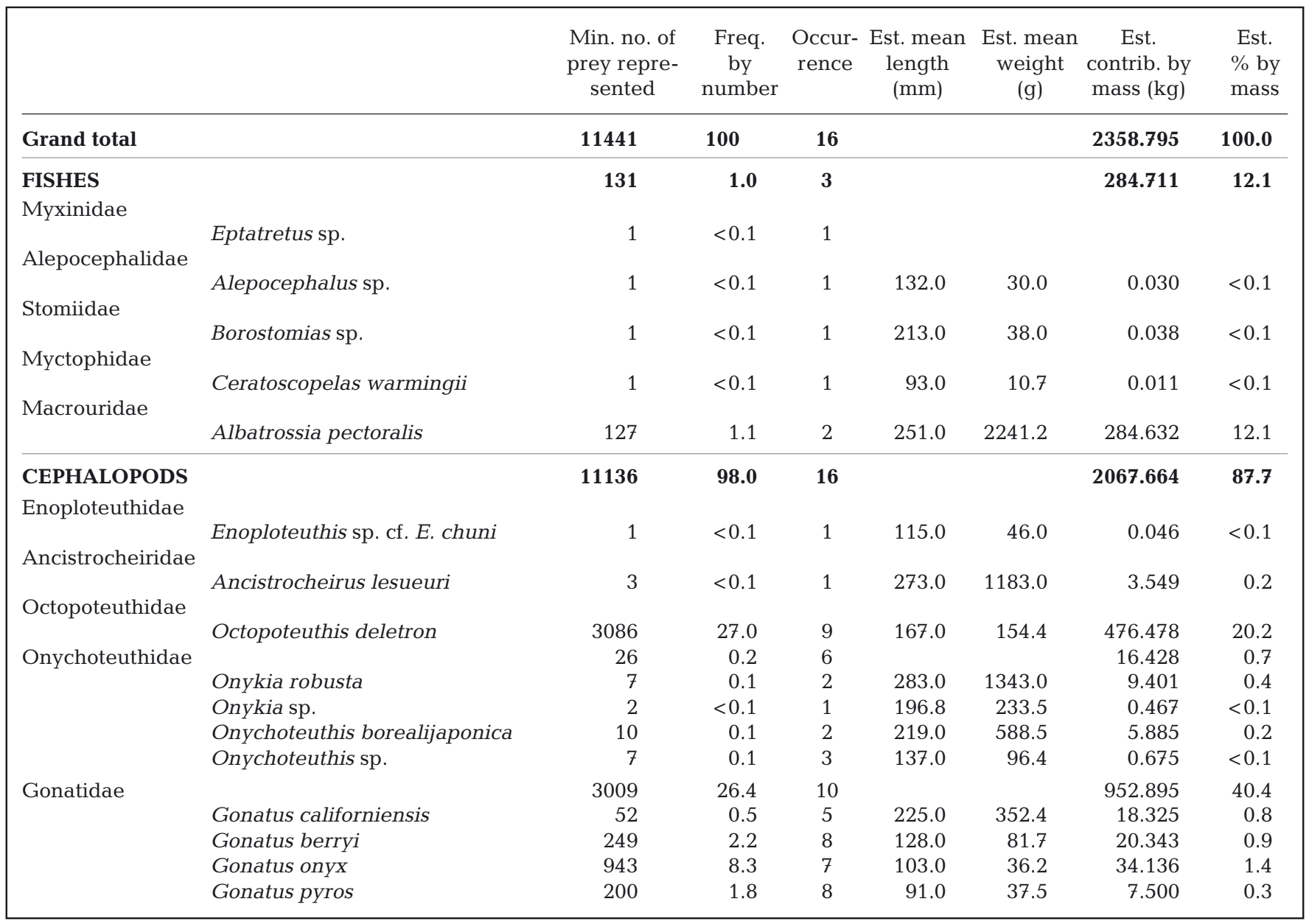


Table 2 (continued)

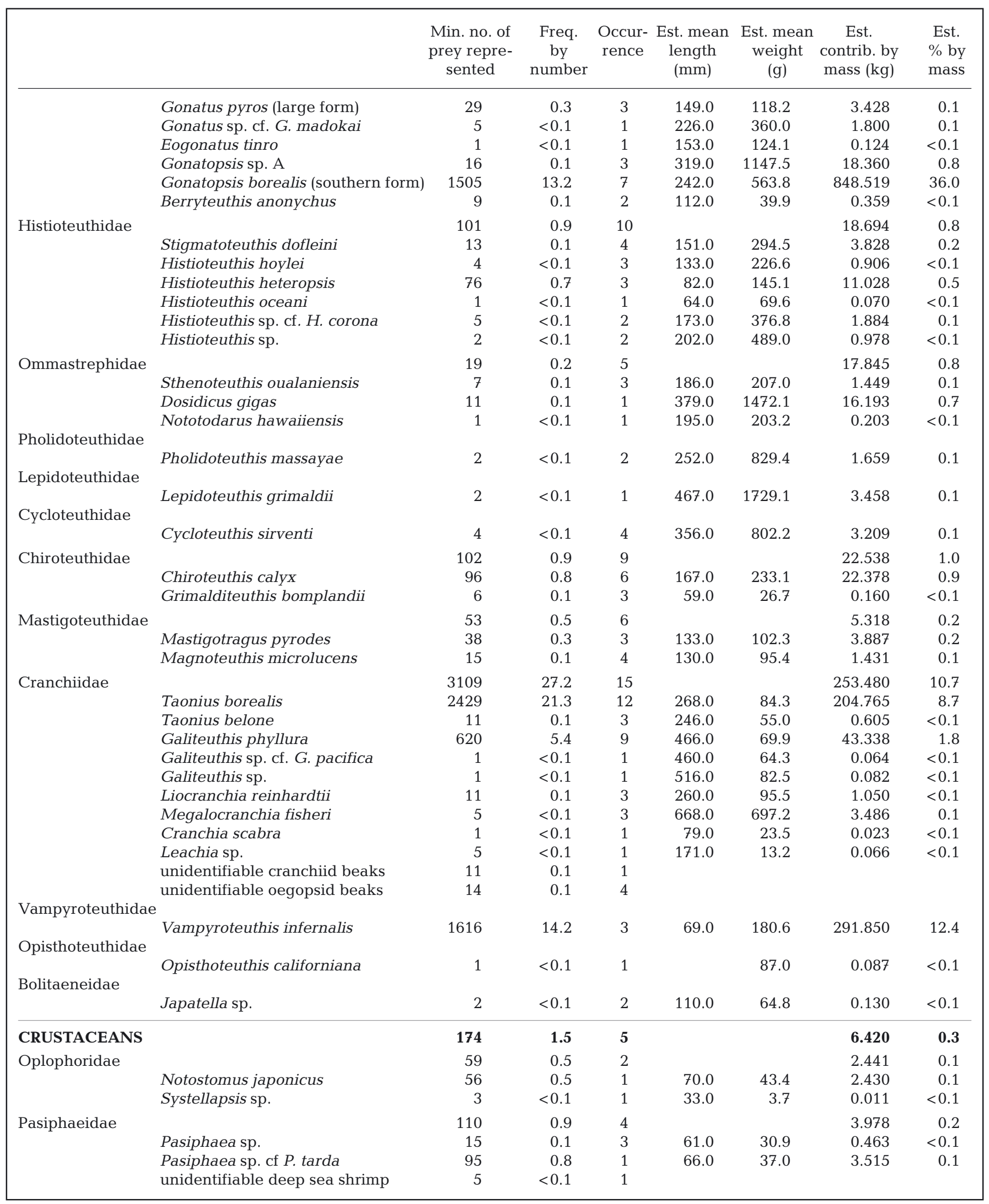



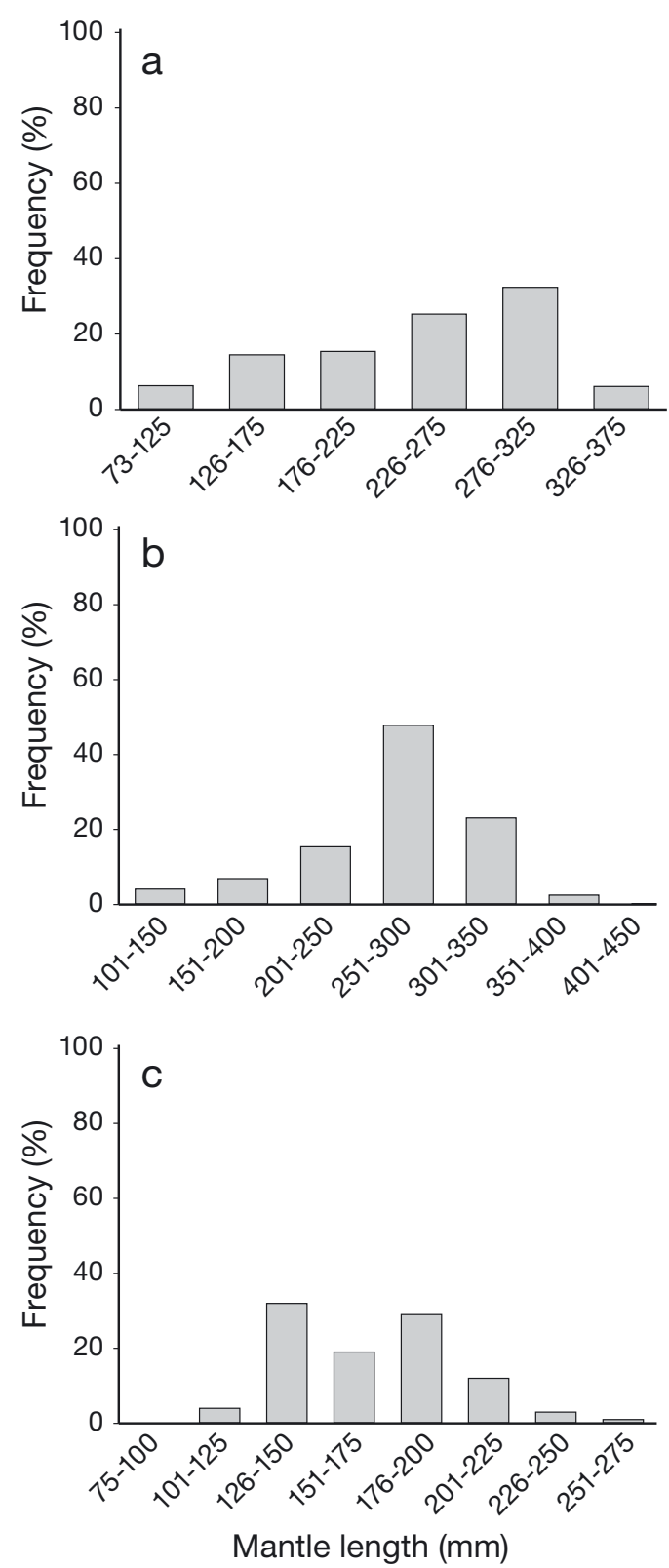

Fig. 4. Estimated dorsal mantle length of (a) Gonatopsis borealis, (b) Taonius borealis, and (c) Octopoteuthis deletron combined from the stomach contents of 16 North Pacific Cuvier's beaked whales Ziphius cavirostris

number $(26.4 \%)$. Of these, Gonatopsis borealis represented $36.0 \%$ of the prey by mass and $13.2 \%$ by number. Prey size estimates (dorsal mantle length) of G. borealis ranged between 73 and $346 \mathrm{~mm}$ (Fig. 4a). The species Gonatus onyx represented $8.3 \%$ of the prey by number but only $1.4 \%$ by mass. The highest contribution to the diet by number was represented by the family Cranchiidae $(27.2 \%)$, with Taonius borealis contributing $21.3 \%$ by number. Cranchiidae contributed less to the diet when considered by prey mass $(10.7 \%)$, with $T$. borealis also contributing most to the diet by mass $(8.7 \%)$. Prey size (dorsal mantle lengths) of $T$. borealis ranged between 107 and $443 \mathrm{~mm}$ (Fig. 4b). The family Octopoteuthidae, represented by 3086 specimens of a single species, Octopoteuthis deletron, contributed $27.0 \%$ by number and $20.2 \%$ by mass (Fig. 3). O. deletron estimated dorsal mantle lengths ranged from 78 to $264 \mathrm{~mm}$ (Fig. 4c). Although only present in 3 stomachs, the family Vampyroteuthidae, represented by the vampire squid Vampyroteuthis infernalis, contributed $14.2 \%$ by number and $12.4 \%$ by mass. The other 12 families of cephalopods represented in the stomachs contributed less than $5 \%$ to the diet by number or mass (Fig. 3a, Table 2).

\section{DISCUSSION}

Predator diets are becoming increasingly recognized as a valuable means to gain information on cephalopod distribution and abundance within oceanic ecosystems (Drazen et al. 2001, Cherel et al. 2004, 2007, Clarke 2006, Staudinger et al. 2013). Predators serve as 'biological samplers,' and cephalopod beaks obtained from stomach contents have also been used to better understand the dynamics of oceanic food webs, especially in the Southern Ocean (e.g. Xavier et al. 2013, Guerreiro et al. 2015, Negri et al. 2016, Seco et al. 2016). In the North Pacific, little information is available on the ecology of cephalopod prey families identified from our study. Cephalopods may inhabit extremely wide depth ranges spanning thousands of meters, and most prey families are believed to undergo both diel vertical migrations and ontogenetic descent, utilizing surface waters as juveniles and moving into deeper waters as they mature (Roper \& Young 1975). Most biological information from the mesopelagic and bathypelagic zones comes from trawl data obtained from research vessels. However, many of the muscular, more mobile cephalopods can avoid capture and are underrepresented in traditional surveys (Wormuth \& Roper 1983). In the case of North Pacific Cuvier's beaked whales, the identification of over 11000 cephalopod prey items, representing at least 45 species, combined with information on the diving behavior of this apex predator (Baird et al. 2006, 2008, Tyack et al. 2006, Schorr et al. 2014) provide insight into beaked whale foraging strategy and serve as a foundation for ecological studies of their prey.

As our samples span the largest ocean basin in the world, we expect some regional differences in prey 
availability and the prey preferences of the whales. However, comparison of generic and family-level prey occurrence can be very useful for gaining insight into a predator's general feeding strategy. We therefore focus on describing prey family-level findings in the North Pacific and how the proportion of prey families represented in the diet of these whales varies on a global scale.

\section{Cephalopod contribution to diet}

Cephalopods were the most important prey to Cuvier's beaked whale diet in the North Pacific, accounting for $98.0 \%$ of the prey by number and $87.7 \%$ by mass with 16 different families represented. Although only negligible in contribution $(<1 \%), 2$ of these cephalopod prey families, Lepidoteuthidae and Opisthoteuthidae, are new to the known diet of the species on a world-wide basis (Table 3). Our study also adds a small contribution by the family Ancistrocheiridae $(<1 \%)$ to the known diet of whales from the North Pacific. Ancistrocheirids have previously been identified from specimens in the North Atlantic and the Mediterranean (Podesta \& Meotti 1991, Carlini et al. 1992, Santos et al. 2007). The family Cycloteuthidae has also been previously reported from the Atlantic (Santos et al. 2001, 2007, Spitz et al. 2011), but was identified for the first time from the North Pacific in negligible amounts $(<1 \%)$. We also confirmed that Mastigoteuthidae contributes negligibly $(<1 \%)$ to the North Pacific diet, while it is more important to the diet of whales in the North Atlantic (Table 3; Santos et al. 2001).

The cephalopod families Gonatidae and Cranchiidae were dominant in the diet of North Pacific beaked whales both in our study and others (Foster \& Hare 1990, Fiscus 1997, Ohizumi \& Kishiro 2003, Adams et al. 2015). Gonatids were found in 10 of 16 whales examined and was the family that accounted for the overall greatest contribution by mass $(40.4 \%)$. They also contributed more to the diet by mass in previously examined specimens from California (83.0\%) and Japan (91.8\%) (Ohizumi \& Kishiro 2003, Adams et al. 2015) and contributed $8.1 \%$ and $51.8 \%$ to the diet by mass from 2 Alaskan whales (Foster \& Hare 1990, Fiscus 1997). Gonatid squids are also recognized as being important to Cuvier's beaked whale diet in the North Atlantic (Santos et al. 2001, Spitz et al. 2011), albeit to a lesser degree than observed in North Pacific whales. Gonatidae contributed less than $2 \%$ by number in South Africa (Ross 1984, Sekiguchi 1994).
On a global scale, the family Cranchiidae appears to be the most important cephalopod family to Cuvier's beaked whale diet based on reports from New Zealand, South Africa, the North Atlantic, and the Mediterranean (Table 3; Fordyce et al. 1979, Ross 1984, Sekiguchi 1994, Blanco \& Raga 2000, Santos et al. 2001, 2007, Kovačić et al. 2010, Spitz et al. 2011). Cranchiid squid contributed between 7.6 and $47.1 \%$ by number in prior studies from the North Pacific (Foster \& Hare 1990, Fiscus 1997, Ohizumi \& Kishiro 2003, Adams et al. 2015). This was also the most common prey family in the stomachs we examined (14 of 16 individuals), accounting for $27.2 \%$ of the diet by number and $10.7 \%$ by mass. Taonius borealis was the most abundant cranchiid species represented. The genus Taonius is characterized by mantle tissue that is amuscular and coriaceous in texture (Nesis 1987). As a result, though extremely abundant, T. borealis has a low body weight and the mass contribution to overall diet was less than half of that by number. Similar to our findings, in all other locations world-wide where Cranchiidae contribution to diet by both number and mass is available, the contribution by number is greater (Blanco \& Raga 2000, Santos et al. 2001, 2007, Ohizumi \& Kishiro 2003, Spitz et al. 2011, Adams et al. 2015).

Histioteuthid squid are the most important prey family to Cuvier's beaked whales inhabiting the Mediterranean and along with members of the family Cranchiidae are the most important prey families to diet in the North Atlantic. In the Mediterranean, histioteuthids dominated the diet, contributing between 21.1 and $94.4 \%$ to diet by number and between 34.7 and $59.7 \%$ by mass where mass estimates were available (Podesta \& Meotti 1991, Carlini et al. 1992, Blanco \& Raga 2000, Kovačić et al. 2010). In the North Atlantic, they contributed between 4.0 and $34.7 \%$ by number and between 3.9 and $31 \%$ by mass (Santos et al. 2001, 2007, Spitz et al. 2011). In contrast, histioteuthids are of lesser importance in the North Pacific, contributing less than $1 \%$ by number and by mass in our study, and in 2 whales previously examined from California and Alaska (Fiscus 1997, Adams et al. 2015).

Octopoteuthidae was also found to be among the most important prey families to North Pacific Cuvier's beaked whale diet. Octopoteuthis deletron specimens ranging in size from 78 to $264 \mathrm{~mm}$ (Fig. 4c) were abundant in our stomach samples, with 3086 individuals identified among the 16 whales. This species was present in over half of the stomachs examined but was most heavily weighted towards SBMNH 8991. O. deletron specimens of a smaller 
Table 3. World-wide summary of prey family contribution to diet by number and by mass for Cuvier's beaked whales Ziphius cavirostris where prey identification from stomach content remains is reported. Stomachs are not included from whales where prey was not identified

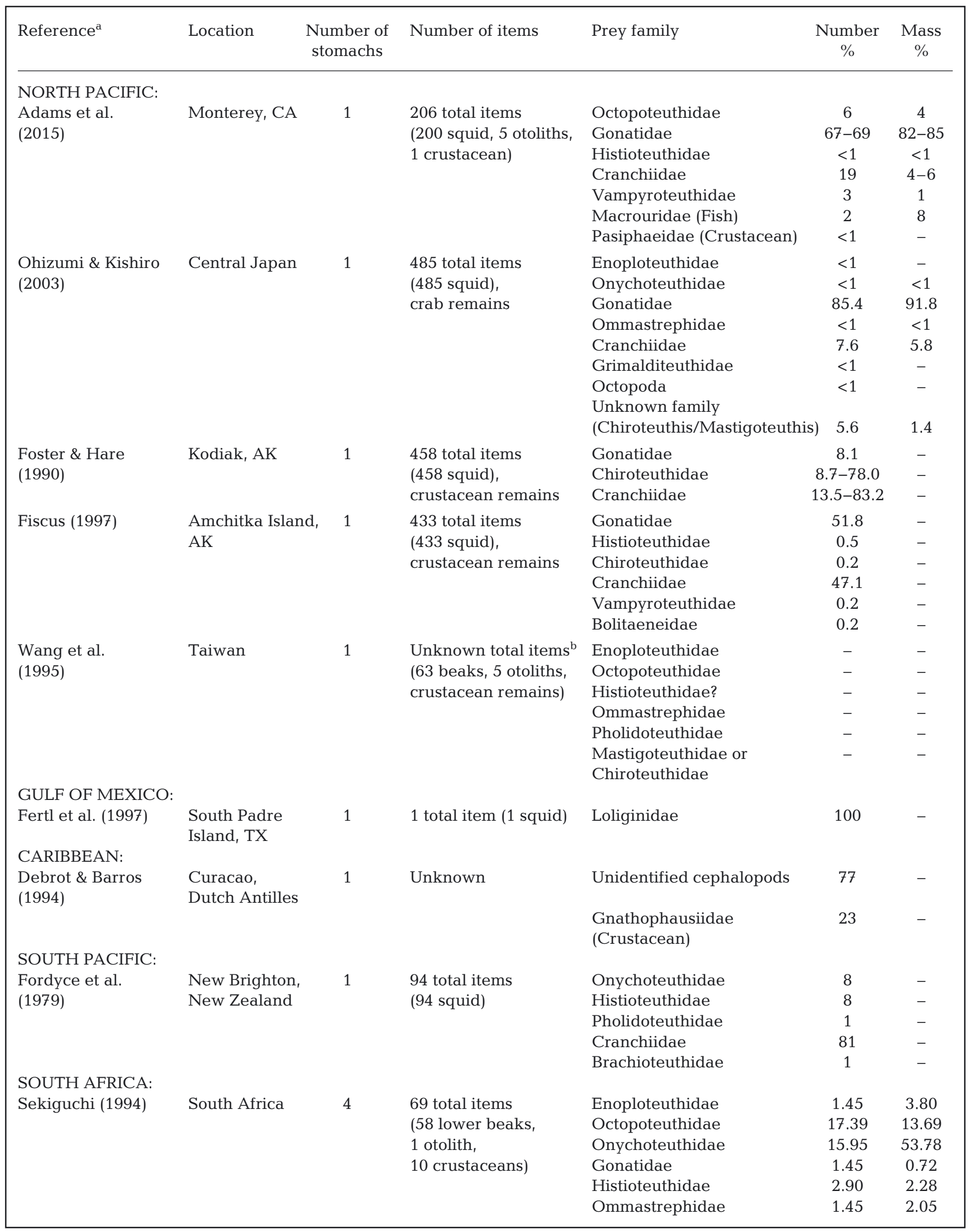


Table 3 (continued)

\begin{tabular}{|c|c|c|c|c|c|c|}
\hline Reference $^{a}$ & Location & $\begin{array}{l}\text { Number of } \\
\text { stomachs }\end{array}$ & Number of items & Prey family & $\underset{\%}{\text { Number }}$ & $\begin{array}{c}\text { Mass } \\
\%\end{array}$ \\
\hline & & & & $\begin{array}{l}\text { Pholidoteuthidae } \\
\text { Chiroteuthidae } \\
\text { Cranchiidae } \\
\text { Gnathophausiidae } \\
\text { (Crustacean) } \\
\text { Unidentified (Fish) }\end{array}$ & $\begin{array}{c}5.80 \\
10.14 \\
27.54 \\
14.49 \\
\\
1.45\end{array}$ & $\begin{array}{c}8.14 \\
1.60 \\
13.51 \\
- \\
-\end{array}$ \\
\hline Ross (1984) & South Africa & 1 & $\begin{array}{l}147 \text { total items } \\
\text { (101 squid, } \\
46 \text { otoliths), } \\
\text { crustacean remains }\end{array}$ & $\begin{array}{l}\text { Octopoteuthidae } \\
\text { Onychoteuthidae } \\
\text { Gonatidae } \\
\text { Histioteuthidae } \\
\text { Ommastrephidae } \\
\text { Chiroteuthidae } \\
\text { Cranchiidae } \\
\text { Lycoteuthidae } \\
\text { Unidentified squid } \\
\text { Moridae (Fish) }\end{array}$ & $\begin{array}{c}8.2 \\
6.1 \\
<1 \\
2.1 \\
<1 \\
12.2 \\
31 \\
<1 \\
7.5 \\
31\end{array}$ & $\begin{array}{l}- \\
- \\
- \\
- \\
- \\
- \\
- \\
- \\
- \\
-\end{array}$ \\
\hline $\begin{array}{l}\text { NORTH ATLANTIC: } \\
\text { Spitz et al. } \\
(2011)\end{array}$ & Bay of Biscay & 10 & $\begin{array}{l}5092 \text { total items } \\
\text { (squid, fishes, salps) }^{\mathrm{c}}\end{array}$ & $\begin{array}{l}\text { Onychoteuthidae } \\
\text { Gonatidae } \\
\text { Histioteuthidae } \\
\text { Ommastrephidae } \\
\text { Cranchiidae } \\
\text { Vampyroteuthidae } \\
\text { Brachioteuthidae } \\
\text { Alloposidae (Octopod) } \\
\text { Stomiidae (Fish) } \\
\text { Gadidae (Fish) } \\
\text { Salp (Invertebrate) }\end{array}$ & $\begin{array}{c}0 \\
2.6 \\
34.7 \\
3.3 \\
39.1 \\
0 \\
1.2 \\
10 \\
0.1 \\
0.1 \\
10\end{array}$ & $\begin{array}{c}0 \\
7.6 \\
31 \\
7.8 \\
33 \\
0 \\
0.1 \\
10 \\
0.1 \\
0.1 \\
10\end{array}$ \\
\hline Santos et al. (2007) & Canary Islands & 7 & $\begin{array}{l}1267 \text { total items } \\
\text { (1267 squid) }\end{array}$ & $\begin{array}{l}\text { Ancistrocheiridae } \\
\text { Octopoteuthidae } \\
\text { Onychoteuthidae } \\
\text { Histioteuthidae } \\
\text { Ommastrephidae } \\
\text { Pholidoteuthidae } \\
\text { Cycloteuthidae } \\
\text { Cranchiidae } \\
\text { Chiroteuthidae } \\
\text { Vampyroteuthidae } \\
\text { Cirroteuthidae }\end{array}$ & $\begin{array}{c}0.08 \\
7.6 \\
1.34 \\
22.2 \\
5.05 \\
0.39 \\
0.71 \\
34.1 \\
9.2 \\
0.08 \\
0.08\end{array}$ & $\begin{array}{r}0.26 \\
0.26 \\
22.3 \\
6.95 \\
24.7 \\
2.95 \\
5.11 \\
6.4 \\
3.04 \\
0.01 \\
0.01\end{array}$ \\
\hline $\begin{array}{l}\text { Santos et al. } \\
(2001)\end{array}$ & $\begin{array}{l}\text { North Uist, } \\
\text { Scotland }\end{array}$ & 1 & $\begin{array}{l}8426 \text { total items } \\
\text { (8426 squid) }\end{array}$ & $\begin{array}{l}\text { Octopoteuthidae } \\
\text { Onychoteuthidae } \\
\text { Gonatidae } \\
\text { Histioteuthidae } \\
\text { Ommastrephidae } \\
\text { Pholidoteuthidae } \\
\text { Cycloteuthidae } \\
\text { Mastigoteuthidae } \\
\text { Chiroteuthidae } \\
\text { Cranchiidae } \\
\text { Bolitaeneidae } \\
\text { Sepiolidae } \\
\text { Chtenopterygidae } \\
\text { Bathyteuthidae } \\
\text { Brachioteuthidae } \\
\text { Cirroteuthidae } \\
\text { Unidentified }\end{array}$ & $\begin{array}{c}0.65 \\
0.2 \\
11.2 \\
9.6 \\
0.28 \\
0.2 \\
0.04 \\
9.54 \\
2.61 \\
45.5 \\
0.02 \\
0.02 \\
0.17 \\
0.01 \\
0.3 \\
0.01 \\
0.17\end{array}$ & $\begin{array}{c}1.7 \\
1.8 \\
26.3 \\
12.7 \\
5.7 \\
4.3 \\
0.3 \\
7.2 \\
2.2 \\
36.8 \\
- \\
- \\
<0.1 \\
- \\
<0.1 \\
- \\
-\end{array}$ \\
\hline Santos et al. (2001) & $\begin{array}{l}\text { A Lanzada, } \\
\text { Spain }\end{array}$ & 1 & $\begin{array}{l}694 \text { total items } \\
\text { (694 squid) }\end{array}$ & $\begin{array}{l}\text { Octopoteuthidae } \\
\text { Gonatidae } \\
\text { Histioteuthidae } \\
\text { Ommastrephidae } \\
\text { Pholidoteuthidae }\end{array}$ & $\begin{array}{c}1.59 \\
4.6 \\
4.0 \\
1.01 \\
1.3\end{array}$ & $\begin{array}{c}2.85 \\
8.96 \\
3.9 \\
13.89 \\
19.51\end{array}$ \\
\hline
\end{tabular}


Table 3 (continued)

\begin{tabular}{|c|c|c|c|c|c|c|}
\hline Reference $^{a}$ & Location & $\begin{array}{l}\text { Number of } \\
\text { stomachs }\end{array}$ & Number of items & Prey family & $\begin{array}{c}\text { Number } \\
\%\end{array}$ & $\begin{array}{c}\text { Mass } \\
\%\end{array}$ \\
\hline & & & & $\begin{array}{l}\text { Cycloteuthidae } \\
\text { Chiroteuthidae } \\
\text { Mastigoteuthidae } \\
\text { Cranchiidae } \\
\text { Stauroteuthidae }\end{array}$ & $\begin{array}{c}0.57 \\
4.17 \\
19.02 \\
54.9 \\
0.14\end{array}$ & $\begin{array}{c}0.7 \\
2.09 \\
11.2 \\
36.9 \\
-\end{array}$ \\
\hline Santos et al. (2001) & $\begin{array}{l}\text { Portonovo, } \\
\text { Spain }\end{array}$ & 1 & $\begin{array}{l}673 \text { total items } \\
\text { ( } 673 \text { squid) }\end{array}$ & $\begin{array}{l}\text { Octopoteuthidae } \\
\text { Gonatidae } \\
\text { Histioteuthidae } \\
\text { Ommastrephidae } \\
\text { Pholidoteuthidae } \\
\text { Chiroteuthidae } \\
\text { Mastigoteuthidae } \\
\text { Cranchiidae } \\
\text { Vampyroteuthidae } \\
\text { Brachioteuthidae } \\
\text { Stauroteuthidae }\end{array}$ & $\begin{array}{c}0.59 \\
3.56 \\
29 \\
1.04 \\
0.15 \\
3.87 \\
5.5 \\
53.8 \\
0.3 \\
0.3 \\
0.15\end{array}$ & $\begin{array}{c}1.8 \\
5.8 \\
18.28 \\
12.27 \\
2.73 \\
2.78 \\
5.0 \\
51.0 \\
0.36 \\
0.03 \\
-\end{array}$ \\
\hline $\begin{array}{l}\text { MEDITERRANEAN } \\
\text { Kovačić et al. } \\
(2010)\end{array}$ & Adriatic Sea & 1 & $\begin{array}{l}99 \text { total items } \\
\text { (99 squid) }\end{array}$ & $\begin{array}{l}\text { Enoploteuthidae } \\
\text { Octopoteuthidae } \\
\text { Histioteuthidae } \\
\text { Chiroteuthidae } \\
\text { Cranchiidae } \\
\text { Sepiolidae }\end{array}$ & $\begin{array}{c}3.4 \\
19.2 \\
21.1 \\
48.5 \\
10.1 \\
1.0\end{array}$ & $\begin{array}{c}0.6 \\
39.1 \\
34.7 \\
17.7 \\
8.2 \\
0.2\end{array}$ \\
\hline $\begin{array}{l}\text { Blanco \& Raga } \\
(2000)\end{array}$ & Pinedo, Spain & 1 & $\begin{array}{l}385 \text { total items } \\
\text { (385 squid) }\end{array}$ & $\begin{array}{l}\text { Octopoteuthidae } \\
\text { Histioteuthidae } \\
\text { Ommastrephidae } \\
\text { Chiroteuthidae } \\
\text { Cranchiidae } \\
\text { Sepiolidae } \\
\text { Chtenopterygidae }\end{array}$ & $\begin{array}{c}2.6 \\
70.6 \\
6.2 \\
1.8 \\
9.4 \\
0.5 \\
5.5\end{array}$ & $\begin{array}{c}1.8 \\
59.7 \\
36.2 \\
0.6 \\
1.3 \\
0.0 \\
0.5\end{array}$ \\
\hline $\begin{array}{l}\text { Blanco \& Raga } \\
(2000)\end{array}$ & Chilches, Spain & 1 & $\begin{array}{l}141 \text { total items } \\
\text { (141 squid) }\end{array}$ & $\begin{array}{l}\text { Enoploteuthidae } \\
\text { Octopoteuthidae } \\
\text { Onychoteuthidae } \\
\text { Histioteuthidae } \\
\text { Ommastrephidae } \\
\text { Chiroteuthidae } \\
\text { Cranchiidae } \\
\text { Chtenopterygidae }\end{array}$ & $\begin{array}{c}2.1 \\
11.3 \\
1.4 \\
24.9 \\
6.4 \\
16.3 \\
24.8 \\
12.8\end{array}$ & $\begin{array}{c}0.2 \\
5.8 \\
0.2 \\
44.3 \\
39.9 \\
5.4 \\
3.1 \\
1.1\end{array}$ \\
\hline $\begin{array}{l}\text { Carlini et al. } \\
\text { (1992) }\end{array}$ & $\begin{array}{l}\text { Tyrrhenian } \\
\text { coast, Italy }\end{array}$ & 1 & $\begin{array}{l}233 \text { total items } \\
\text { (233 squid) }\end{array}$ & $\begin{array}{l}\text { Ancistrocheiridae } \\
\text { Octopoteuthidae } \\
\text { Histioteuthidae } \\
\text { Ommastrephidae } \\
\text { Chiroteuthidae } \\
\text { Sepiolidae }\end{array}$ & $\begin{array}{c}1.7 \\
0.4 \\
94.4 \\
1.3 \\
0.4 \\
0.4\end{array}$ & $\begin{array}{l}- \\
- \\
- \\
- \\
- \\
-\end{array}$ \\
\hline $\begin{array}{l}\text { Podesta \& } \\
\text { Meotti (1991) }\end{array}$ & $\begin{array}{l}\text { Sardinia, } \\
\text { Italy }\end{array}$ & 1 & $\begin{array}{l}79 \text { total items } \\
\text { (79 squid) }\end{array}$ & $\begin{array}{l}\text { Ancistrocheiridae } \\
\text { Octopoteuthidae } \\
\text { Onychoteuthidae } \\
\text { Histioteuthidae } \\
\text { Unidentified }\end{array}$ & $\begin{array}{c}22.7 \\
2.5 \\
1.3 \\
65.8 \\
7.6\end{array}$ & $\begin{array}{l}- \\
- \\
- \\
- \\
-\end{array}$ \\
\hline $\begin{array}{l}\text { Lefkaditou \& } \\
\text { Poulopoulos (1998) }\end{array}$ & Greece & 7 & 66 total items ${ }^{\mathrm{d}}$ & $\begin{array}{l}\text { Octopoteuthidae } \\
\text { Histioteuthidae }\end{array}$ & $\begin{array}{l}47.4 \\
39.5\end{array}$ & $\begin{array}{l}- \\
-\end{array}$ \\
\hline
\end{tabular}


average size contributed $6 \%$ to the diet by number and $4 \%$ by mass in a stranded Monterey, California, whale (Adams et al. 2015). Octopoteuthid squid beaks were identified but not quantified in a stomach from Taiwan (Wang et al. 1995), and Octopoteuthidae contributed between 8.2 and $17.4 \%$ to the diet by number and $13.7 \%$ by mass in South Africa (Sekiguchi 1994). In the Bay of Biscay and in Scotland, Octopoteuthidae contributed less than $2 \%$ to the diet of the whales by number (Santos et al. 2001, Spitz et al. 2011). In the Canary Islands, Octopoteuthidae contributed $7.6 \%$ by number but contributed less than $1 \%$ by mass (Santos et al. 2007). Octopoteuthidae may be more important to diet in the Mediterranean with prey importance ranging widely among studies, between 0.4 and $47 \%$ by number and 1.8 and $39.1 \%$ by mass (Podesta \& Meotti 1991, Carlini et al. 1992, Lefkaditou \& Poulopoulos 1998, Blanco \& Raga 2000, Kovačić et al. 2010)

Ommastrephidae and Onychoteuthidae are sometimes identified as important cephalopod prey to Cuvier's beaked whales from other regions but were present in only small amounts $(<1 \%)$ by number and by mass in the North Pacific (Table 2). In our study, ommastrephids were only identified from specimens in sub-tropical waters (Panama, Hawai'i, Guam, and Saipan), and 11 specimens of the species Dosidicus gigas were found only in the Panama whale. In prior studies, Ommastrephidae was identified from Japan in negligible amounts $(<1 \%$ ) (Ohizumi \& Kishiro 2003) and contributed less than $1 \%$ by number from whales in the Bay of Biscay, but mass contribution ranged between 7.8 and 13.9\% (Santos et al. 2001, Spitz et al. 2011). In a study from the Mediterranean, Ommastrephidae contributed $39.9 \%$ by mass and only $6.4 \%$ by number (Blanco \& Raga 2000). Similarly, the family Onychoteuthidae contributed significantly to the diet of whales in the Canary Islands by mass $(7.0 \%)$ but only $1.3 \%$ by number (Santos et al. 2007). In New Zealand, onychoteuthids contributed $8 \%$ to the diet by number, but mass was not available for comparison (Fordyce et al. 1979). As in our study, onychoteuthid dietary contributions under $2 \%$ have previously been described from Japan, the Bay of Biscay, Scotland, and the Mediterranean Sea (Podesta \& Meotti 1991, Blanco \& Raga 2000, Santos et al. 2001, Ohizumi \& Kishiro 2003, Spitz et al. 2011). Both ommastrephid and onychoteuthid squid are commonly associated with the epipelagic zone (Nesis 1987). However, they are also known to range into lower mesopelagic depths where they could be taken in small numbers by deep-diving cetaceans. Adult members of both of these families are typically large and muscular, accounting for a greater contribution by mass relative to number.

The vampire squid family Vampyroteuthidae contributed significantly $(14.2 \%$ by number and $12.1 \%$ by mass) to the North Pacific Cuvier's beaked whale diet (Fig. 3). However, all but 3 of the 1616 vampire squid specimens were found in SBMNH 8991. With such an extreme bias towards 1 individual, the importance of the vampire squid to the overall diet of North Pacific whales may be over-emphasized in our study. Vampire squid contributed $3 \%$ by number and $1 \%$ by mass to the diet of the whale from Monterey (Adams et al. 2015) and have previously been reported in negligible amounts in Cuvier's beaked whales from Alaska, the Bay of Biscay, and the Canary Islands (Fiscus 1997, Santos et al. 2001, 2007, Spitz et al. 2011).

Pholidoteuthidae was present but did not significantly contribute to diet in North Pacific Cuvier's beaked whales. However, this cephalopod family has been identified as important to prey mass in South Africa (8\%), Scotland (4.3\%), and the Canary Islands (5\%) and accounted for almost $20 \%$ of the prey mass in a whale examined off the Atlantic coast of Spain (Sekiguchi 1994, Santos et al. 2001, 2007). Chiroteuthidae only contributed trace amounts and Chtenopterygidae was not represented in the North Pacific sample but both families may be important to diet in the Mediterranean (Blanco \& Raga 2000, Kovačić et al. 2010).

\section{Fish contribution to diet}

Five families of fishes were represented among the stomach content remains of the North Pacific whales. Only 2 of these families, Macrouridae and Stomiidae, have previously been reported in the world-wide diet of Cuvier's beaked whales (Spitz et al. 2011, Adams et al. 2015), and we add the fish families Myctophidae and Alepocephalidae to the known diet based on a specimen from Guam. We also add Myxinidae to the known diet of this species. However, with the exception of giant grenadier (Macrouridae), the other 4 species of fishes identified among the whales in our study were single specimens that were negligible in their mass contribution to overall diet.

Cuvier's beaked whales obtained from a Japanese fishery were reported to prey primarily on unidentified deepwater fishes when captured in water greater than 1000 m (Nishiwaki \& Oguro 1972), but otherwise a significant contribution by fishes to the diet of Cuvier's beaked whales is rare. Five otoliths 
were present among remains from a whale in Taiwan (Wang et al. 1995), and in South Africa 36 otoliths of the codling family, Moridae, were present in 1 whale and an unidentified otolith in another (Ross 1984, Sekiguchi 1994). In our study, the giant grenadier (family Macrouridae) represented $12.1 \%$ of the overall diet by mass but a much smaller amount by number $(1.1 \%)$. Despite a significant contribution to prey mass, this species was present in only 2 of the whales examined, both of which stranded in California. The giant grenadier contributed $2 \%$ by number and $8 \%$ by mass in a stranded specimen examined from Monterey, California (Adams et al. 2015). The longer preanal fin lengths (199-350 mm; Fig. 2) compared to the prior report of 140-180 mm (Adams et al. 2015) explains the greater prey mass $(12.1 \%)$ observed in our study. Our findings and those of Adams et al. (2015) signify the greatest contribution of fishes (8$12.1 \%$ by mass) quantified to date and suggest that fishes may be important to diet of these whales on a regional scale.

Macrourid fishes are among the dominant deepsea fishes and have been described from a benthic slope habitat between 200 and $2170 \mathrm{~m}$ along the Pacific Rim, including waters off of southern California, Oregon, the Bering Sea, and Japan (Novikov 1970, Iwamoto \& Stein 1974). The giant grenadier contributes significantly to biomass in the 1098$1280 \mathrm{~m}$ depth range along the continental slope of North America (Lauth 1999). Considering the abundance of this fish and its preferred continental slope habitat, it is not surprising that the giant grenadier contributed significantly by mass to the diet of SBMNH 8991.

What is known of Cuvier's beaked whale diving behavior aligns with the giant grenadier habitat. In the Ligurian Sea, Cuvier's beaked whales echolocate in water depths between 222 and $1885 \mathrm{~m}$, with active foraging believed to occur during dives that averaged $1070 \mathrm{~m}$ in depth (Tyack et al. 2006). Cuvier's beaked whales routinely dive to depths exceeding $800 \mathrm{~m}$ off Hawai'i (Baird et al. 2006) and dive to a mean depth of $1401 \mathrm{~m}$ off southern California (Schorr et al. 2014). The deepest $(2992 \mathrm{~m})$ and longest (137.5 min) dives for any mammal were recorded from Cuvier's beaked whales off southern California, where the most hours of dive data have been collected (Schorr et al. 2014). The extreme diving behavior of Cuvier's beaked whales indicate that the deep mesopelagic and bathypelagic zones are important foraging grounds for this species.

The giant grenadier diet (by mass) is represented by Gonatidae, Octopoteuthis spp., fish remains, and a small contribution by the vampire squid (Drazen et al. 2001). Octopoteuthis deletron and V. infernalis were also abundant among the prey remains of SBMNH 8991 and were also present in the stranded whale from Monterey that preyed on the giant grenadier (Adams et al. 2015). It is possible that some of the smaller beaks of $O$. deletron and $V$. infernalis in SBMNH 8991 were introduced secondarily as prey of giant grenadier. However, we suspect that the effect of potential secondary ingestion was minimal. The beak condition and comparatively large estimated size of these 2 species in our samples suggests they were preyed upon directly. In addition, O. deletron was identified among the stomach content remains of 7 other whales in our study that did not have evidence of foraging on the giant grenadier or other large fishes. Similarly, gonatid squid were represented in most of the North Pacific whales that did not have any fish remains in their stomachs.

\section{Crustacean contribution to diet}

Crustaceans representing at least 3 species from the families Pasiphaeidae and Oplophoridae were found to contribute a small amount to the diet, with crustaceans present in almost a third of the stomachs examined (5/16). Crustaceans appeared to be a significant part of the diet for the 5 whales, ranging between 30 and $68.3 \%$ of the prey by number. Crustaceans contributed to the diet of all 3 of the individuals examined from the Western Pacific (2 from Guam and 1 from Saipan). Similarly in Taiwan, the stomach contents of 3 stranded whales all contained unidentified crustacean remains (Wang et al. 1995). Our findings from the Mariana Islands archipelago combined with the Taiwan report suggest that crustaceans may be especially important prey to Cuvier's beaked whales that inhabit the Western Pacific.

The deep water shrimp families Pasiphaeidae and Gnathophausiidae are the most commonly described crustaceans in the diet of Cuvier's beaked whales (Table 3). In the North Pacific, remains from Pasiphaeidae have previously been reported from Alaska and California (Foster \& Hare 1990, Adams et al. 2015). Pasiphaeidae was present in 4 of 5 stomachs with crustacean remains in our study and appears to be the dominant crustacean in North Pacific whales. Gnathophausiidae has not been reported to date from Cuvier's beaked whales in the Pacific but is the dominant crustacean in their diet from other regions including the Caribbean and South Africa (Table 3; Debrot \& Barros 1994, Sekiguchi 1994). 
Pasiphaeidae and Gnathophausiidae shrimps are both widely distributed in the world's oceans. In the Atlantic, Pasiphaea tarda is the most common representative of the Pasiphaeidae family found in Cuvier's beaked whale stomachs and has been reported from deep waters off Scotland and in the Pacific from trawls between 880 and 960 m off Australia (Hanamura \& Evans 1994, Bullough et al. 2001). The reported trawl depths are in close agreement with Cuvier's beaked whale foraging activity based around a likely upper limit of $600 \mathrm{~m}$ and a lower limit of almost 3000 m (Baird et al. 2006, Tyack et al. 2006, Schorr et al. 2014).

In addition to the Pasiphaeidae and Gnathophausiidae shrimps, our findings identified the presence of Notostomus japonicus and Systellapsis spp. in small amounts ( $<1 \%$ by number and mass), which represents the first report of the Oplophoridae family in the diet of Cuvier's beaked whales world-wide. We did not find other invertebrates among the stomach content remains of the North Pacific whales, but crabs have been previously identified among the remains of an individual from Japan (Ohizumi \& Kishiro 2003), and salps contributed $10 \%$ to the diet by both number and mass in the Bay of Biscay (Spitz et al. 2011). It is likely that some invertebrate prey is underrepresented in cetacean stomachs, as softbodied or fragile invertebrates such as shrimp and salps lack resistant hard parts and are susceptible to rapid digestion.

Cuvier's beaked whales are the most likely species to strand coincident with underwater noise (D'Amico et al. 2009). Tagged beaked whales have also been shown to respond behaviorally to navy sonar by ceasing deep foraging dives and moving away (Tyack et al. 2011, DeRuiter et al. 2013), but their vulnerability remains poorly understood. A component has been a historical lack of information on normal foraging patterns, preferred prey, and habitat usage, and our dietary findings contribute to filling this gap in North Pacific Cuvier's beaked whales. Additionally, there is concern that North Pacific beaked whales may be in decline (Moore \& Barlow 2013), and attempts to model beaked whale survival and reproduction have emphasized the need for more comprehensive data on beaked whale prey species. The average energy content of prey was recognized as the main driver of depressed survival and reproduction, but estimates are likely inaccurate since 6 extant beaked whale species failed to survive based on current model predictions (New et al. 2013). Both in the modeling of beaked whale energetics and in an approach to quantify the daily consumption of cephalopods in a marine protected area used by northern bottlenose whales Hyperoodon ampullatus, the average caloric value of the prey was usually based on only 1 prey species (Hooker et al. 2002, New et al. 2013). Although caloric energy estimates are available from the Gonatidae family (Clarke et al. 1985, Hooker et al. 2002, Sinclair et al. 2015), calculating energetic requirements from only 1 prey species may be overly simplistic, as North Pacific Cuvier's beaked whales eat a diverse diet represented by at least 45 prey species. These findings from primarily stranded Cuvier's beaked whales are believed to represent the freeranging Cuvier's diet based on prey comparisons between stranded and non-stranded dolphins (Dunshea et al. 2013). Further work to determine the caloric value of a suite of prey species identified as important to beaked whales would increase the value of predictive modeling as well as our understanding of beaked whale nutritional needs and the impact of displacement from rich foraging grounds.

Acknowledgements. Funding for the examination of stomach contents and prey identification was provided by the Office of Naval Research, Award number N00014-14-10412. The NOAA Prescott grant program supported the collection of samples from stranded specimens in Saipan, Guam, and Hawai'i. We are grateful to Valerie Brown and Brent Tibbatts in Guam and to the many volunteers who supported stranding response efforts across the North Pacific. F. David Horgen reviewed the manuscript.

\section{LITERATURE CITED}

Adams J, Walker WA, Burton EJ, Harvey JT (2015) Stomach contents of a Cuvier's beaked whale (Ziphius cavirostris) stranded in Monterey Bay, California. Northwest Nat 96: 93-98

Baird RW, Webster DL, McSweeney DJ, Ligon AD, Schorr GS, Barlow J (2006) Diving behaviour of Cuvier's (Ziphius cavirostris) and Blainville's (Mesoplodon densirostris) beaked whales in Hawai'i. Can J Zool 84: 1120-1128

Baird RW, Webster DL, Schorr GS, McSweeney DJ, Barlow J (2008) Diel variation in beaked whale diving behavior. Mar Mamm Sci 24:630-642

*Banco C, Raga JA (2000) Cephalopod prey of two Ziphius cavirostris (Cetacea) stranded on the western Mediterranean coast. J Mar Biol Assoc UK 80:381-382

Bullough L, Napier I, Riley D (2001) Exploratory fishing for deep water shrimp to the north and west of Scotland. Fish Dev Note 13:1-4

Carlini R, Pulcini M, Wurtz M (1992) Cephalopods from the stomachs of Cuvier's beaked whale (Ziphius cavirostris Cuvier, 1823) stranded at Fiumino, Central Tyrrhenian Sea. In: Evans PGH (ed) Proceedings of the 6th Annual Conference of the European Cetacean Society, San Remo, Italy, 20-22 February 1992. European Research on Cetaceans 6. European Cetacean Society, Cambridge, p 190-191 
Cherel Y, Duhamel G, Gasco N (2004) Cephalopod fauna of subantarctic islands: new information from predators. Mar Ecol Prog Ser 266:143-156

Cherel Y, Sabatié R, Potier M, Marsac F, Ménard F (2007) New information from fish diets on the importance of glassy flying squid (Hyaloteuthis pelagica) (Teuthoidea: Ommastrephidae) in the epipelagic cephalopod community of the tropical Atlantic Ocean. Fish Bull 105:147-152

* Childress JJ, Price MH (1983) Growth rate of the bathypelagic crustacean Gnathophausia ingens (Mysidacea: Lophogastridae). Mar Biol 76:165-177

Clarke M (1986) Cephalopods in the diet of odontocetes. In: Bryden MM, Harrison R (eds) Research on dolphins. Clarendon Press, Oxford, p 281-321

Clarke MR (2006) Oceanic cephalopod distribution and species diversity in the eastern North Atlantic. Arquipel Life Mar Sci 23A:27-46

* Clarke A, Clarke MR, Holmes LJ, Waters TD (1985) Calorific values and elemental analysis of eleven species of oceanic squids (Mollusca: Cephalopoda). J Mar Biol Assoc UK 65: 983-986

Cox TM, Ragen TJ, Read AJ, Vos E and others (2006) Understanding the impacts of anthropogenic sound on beaked whales. J Cetacean Res Manag 7:177-187

D'Amico A, Gisner RC, Ketten DR, Hammock JA, Johnson D, Tyack PL, Mead J (2009) Beaked whale strandings and naval exercises. Aquat Mamm 35:452-472

Debrot AO, Barros NB (1994) Additional cetacean records for the leeward Dutch Antilles. Mar Mamm Sci 10:359-368

* DeRuiter SL, Southall BL, Calambokidis J, Zimmer WMX and others (2013) First direct measurements of behavioural responses by Cuvier's beaked whales to mid-frequency active sonar. Biol Lett 9:20130223

* Drazen JC, Buckley TW, Hoff GR (2001) The feeding habits of slope dwelling macrourid fishes in the eastern North Pacific. Deep Sea Res I 48:909-935

Dunshea G, Barros NB, Berens McCabe EJ, Gales NJ, Hindell MA, Jarman SN, Wells RS (2013) Stranded dolphin stomach contents represent the free-ranging population's diet. Biol Lett 9:201210236

Fertl D, Schiro AJ, Collier S, Worthy GAJ (1997) Stranding of a Cuvier's beaked whale (Ziphius cavirostris) in southern Texas, with comments on stomach contents. Gulf Mex Sci 2:92-93

Fiscus CH (1997) Cephalopod beaks in a Cuvier's beaked whale (Ziphius cavirostris) from Amchitka Island, Alaska. Mar Mamm Sci 13:481-486

Fordyce RE, Mattlin RH, Wilson GJ (1979) Stranding of a Cuvier's beaked whale Ziphius cavirostris Cuvier, 1823, at New Brighton, New Zealand. Mauri Ora 7:73-82

Foster NR, Hare MP (1990) Cephalopod remains from a Cuvier's beaked whale (Ziphius cavirostris) stranded in Kodiak, Alaska. Northwest Nat 71:49-51

Guerreiro M, Phillips RA, Cherel Y, Ceia FR, Alvito P, Rosa R, Xavier JC (2015) Habitat and trophic ecology of Southern Ocean cephalopods from stable isotope analyses. Mar Ecol Prog Ser 530:119-134

Hanamura Y, Evans DR (1994) Deepwater caridean shrimps of the families Oplophoridae and Pasiphaeidae (Crustacea: Decapoda) from western Australia, with an appendix on a lophogastridan mysid (Mysidacea). Crustac Res 23:46-60

Heyning JE, Mead JG (2009) Cuvier's beaked whale, Ziphius cavirostris. In: Perrin WF, Wursig B, Thewissen JGM (eds) Encyclopedia of marine mammals. Academic
Press, San Diego, CA, p 294-295

*Hooker SK, Whitehead H, Gowans S (2002) Ecosystem consideration in conservation planning: energy demand of foraging bottlenose whales (Hyperoodon ampullatus) in a marine protected area. Biol Conserv 104:51-58

Iwamoto T, Stein DL (1974) A systematic review of the rattail fishes (Macrouridae: Gadiformes) from Oregon and adjacent waters. Occas Pap Calif Acad Sci 111:1-79

*Kovačić I, Đuras Gomerčić M, Gomerčić H, Lucić $H_{\text {, }}$ Gomerčić T (2010) Stomach contents of two Cuvier's beaked whales (Ziphius cavirostris) stranded in the Adriatic Sea. Mar Biodivers Rec 3:e19

Lauth RR (1999) The 1997 Pacific west coast upper continental slope trawl survey of groundfish resources of Washington, Oregon, and California: estimates of distribution, abundance, and length composition. Tech Memo NMFSAFSC-98. U.S. Department of Commerce, NOAA

Lefkaditou E, Poulopoulos Y (1998) Cephalopod remains in the stomach content of beaked whales, Ziphius cavirostris (Cuvier, 1823) from the Ionian Sea. Rapp Comm Int Mer Medit 35:460-461

* Moore JE, Barlow JP (2013) Declining abundance of beaked whales (Family Ziphiidae) in the California Current large marine ecosystem. PLOS ONE 8:e52770

Negri A, Daneri G, Ceia F, Vieira R and others (2016) The cephalopod prey of the Weddell seal, Leptonychotes weddellii, a biological sampler of the Antarctic marine ecosystem. Polar Biol 39:561-564

Nesis KN (1987) Cephalopods of the world: squids, cuttlefishes, octopuses, and allies. T.F.H. Publications Inc., Neptune City, NJ

New LF, Moretti DJ, Hooker SK, Costa DP, Simmons SE (2013) Using energetic models to investigate the survival and reproduction of beaked whales (family Ziphiidae). PLOS ONE 8:e68725, doi:10.1371/journal.pone.0068725

Nishiwaki M, Oguro N (1972) Catch of the Cuvier's beaked whales off Japan in recent years. Sci Rep Whales Res Inst 24:35-41

Novikov NP (1970) Biology of Chalinura pectoralis in the North Pacific. In: Moiseev PA (ed) Soviet fisheries investigations in the Northeastern Pacific. Part V, Vol 7. VINRO, Trudy, p 304-331

Ohizumi H, Kishiro T (2003) Stomach contents of a Cuvier's beaked whale (Ziphius cavirostris) stranded on the central Pacific coast of Japan. Aquat Mamm 29:99-103

Podesta M, Meotti C (1991) The stomach contents of a Cuvier's beaked whale, Ziphius cavirostris and a Risso's dolphin, Grampus griseus, stranded in Italy. In: Evans PGH (ed) Proceedings of the Fifth Conference of the European Cetacean Society, Sandefjord, Norway, 21-23 February 1991. European Research on Cetaceans 5. European Cetacean Society, Cambridge, p 58-61

Roper CFE, Young RE (1975) Vertical distribution of pelagic cephalopods. Smithson Contrib Zool 209:1-51

Ross GJB (1984) The smaller cetaceans of the south east coast of southern Africa. Annals of the Cape Provincial Museums, Part 2, Vol 15. Cape Provincial Museums, Grahamstown

Santos MB, Pierce GJ, Herman J, López A, Guerra A, Mente E, Clarke MR (2001) Feeding ecology of Cuvier's beaked whale (Ziphius cavirostris): a review with new information on the diet of this species. J Mar Biol Assoc UK 81: $687-694$

Santos MB, Martin V, Arbelo M, Fernandez A, Pierce GJ (2007) Insights into the diet of beaked whales from the 
atypical mass stranding in the Canary Islands in September 2002. J Mar Biol Assoc UK 87:243-251

Schorr GS, Falcone EA, Moretti DJ, Andrews RD (2014) First long-term behavioral records from Cuvier's beaked whales (Ziphius cavirostris) reveal record-breaking dives. PLOS ONE 9:e92633

Seco J, Roberts J, Ceia F, Baeta A, Ramos JA, Paiva V, Xavier JC (2016) Distribution, habitat and trophic ecology of Antarctic squid Kondakovia longimana and Moroteuthis knipovitchi; inferences from predators and stable isotopes. Polar Biol 39:167-175

Sekiguchi K (1994) Studies on feeding habits and dietary analytical methods for smaller odontocete species along the southern African coast. PhD dissertation. University of Pretoria

Sinclair EH, Walker WA, Thomason JR (2015) Body size regression formulae, proximate composition and energy density of Eastern Bering Sea mesopelagic fish and squid. PLOS ONE 10:e0132289

Smale MJ, Watson G, Hecht T (1995) Otolith atlas of southern African marine fishes. Icthyological Monographs of the J.L.B. Smith Institute of Ichthyology, Grahamstown

Spear LB, Ainley DG, Walker WA (2007) Foraging dynamics of seabirds in the eastern tropical Pacific ocean. Stud Avian Biol 35:1-99

Spitz J, Cherel Y, Bertin S, Kiszka J, Dewez A, Ridoux V (2011) Prey preferences among the community of deepdiving odontocetes from the Bay of Biscay, Northeast Atlantic. Deep Sea Res I 58:273-282

Editorial responsibility: Rory Wilson, Swansea, UK
Staudinger MD, Juanes F, Salmon B, Teffer AK (2013) The distribution, diversity, and importance of cephalopods in top predator diets from offshore habitats of the Northwest Atlantic Ocean. Deep Sea Res II 95:182-192

Tyack PL, Johnson M, Soto NA, Sturlese A, Madsen PT (2006) Extreme diving of beaked whales. J Exp Biol 209: 4238-4253

Tyack PL, Zimmer WMX, Moretti D, Southall BL and others (2011) Beaked whales respond to simulated and actual navy sonar. PLOS ONE 6:e17009

Wang JY, Chou LS, Yao CJ, Neimanis AS, Chou WH (1995) Records of Cuvier's beaked whales (Ziphius cavirostris) from Taiwan, Republic of China. Asian Mar Biol 12: 111-118

Wolff GA (1982) A beak key for eight eastern tropical Pacific cephalopod species with relationships between their beak dimensions and size. Fish Bull 80:357-371

Wolff GA (1984) Identification and estimation of size from the beaks of 18 species of cephalopods from the Pacific ocean. Tech Rep 17. National Oceanic and Atmospheric Administration, National Marine Fisheries Service, La Jolla, CA

Wormuth JH, Roper CF (1983) Quantitative sampling of oceanic cephalopods by nets: problems and recommendations. Biol Oceanogr 2:357-377

Xavier JC, Louzao M, Thorpe SE, Ward P and others (2013) Seasonal changes in the diet and feeding behaviour of a top predator indicates a flexible response to deteriorating oceanographic conditions. Mar Biol 160:1597-1606

Submitted: September 12, 2016; Accepted: May 24, 2017 Proofs received from author(s): June 28, 2017 